\title{
The Veltro and Dante's Prologue to the Commedia
}

The prophecy of the Veltro is perhaps the most famous puzzle of the Commedia and the one which has most fascinated and baffled the reader. ${ }^{1}$ As is well known, the Veltro is a hunting hound and in the poem it is taken to refer to the person who will defeat the malicious she-wolf and restore Italy to health:

Molti son li animali a cui s'ammoglia,

e piú saranno ancora, infin che 'l veltro

verrà, che la farà morir con doglia.

Questi non ciberà terra né peltro,

ma sapienza, amore e virtute,

e sua nazion sarà tra feltro e feltro.

Di quella umile Italia fia salute

per cui morí la vergine Cammilla,

Eurialo e Turno e Niso di ferute. (Inf. I. 100-08)

The solutions to the identity of the Veltro suggested over the years have been many and varied. The general tendency has been to look for an historical or even a fictional character who could answer to the larger-than-life requirements set for the Veltro. A pope, a monarch, a mythic character, a messiah have been the reasonable guesses which, nonetheless, have failed to persuade the reader. Jean Pépin, in his study on Dante's allegory, reviews the most credible interpretations to date and singles out that of R.E. Kaske (but mainly for his reading of the DXV - another puzzle of the Commedia) as being the most sober and the most feasible, "qui se recommende par sa sobriété et sa vraisemblance." 2 Kaske suggests that the Veltro is a group of reformers made up of Franciscans and Benedictines. ${ }^{3}$

One of the major obstacles in resolving the riddle has been to find a candidate who would fit the description of the Hound. Although the names of Can Grande Della Scala (the name means Great Dog) and of other noble historical figures would seem to fit 
the description, these personages were never known to have accomplished what is claimed of them in the prophecy. ${ }^{4}$ The lack of such an outstanding figure who dominates the political world of Dante's times has led critics to believe that the episode, as many other in the poem, expresses Dante's hope for a strong political leadership that never materialized. "It is also one of various utterances, all intentionally cryptic, in the course of the poem of his undying hope for the advent of a heroic deliverer of the world from the present power of evil." 5

For these reasons, the episode of the Veltro is also thought not to be thematically relevant to the rest of the canto, or to the rest of the poem. The prophecy is taken to be an aside expressing a hope that remains unfulfilled both in the poem and in history. This is borne out by the narrative events of this first canto in the failed attempt of the pilgrim to ascend the "dilettoso monte" (Inf. I. 77) because of the interference of the she-wolf:

Vedi la bestia per $\mathrm{cu}^{\prime}$ io mi volsi; aiutami da lei, famoso saggio,

ch'ella mi fa tremar le vene e i polsi".

"A te convien tenere altro viaggio", rispuose, poi che lagrimar mi vide,

"se vuo' campar d'esto loco selvaggio;

ché questa bestia, per la qual tu gride, non lascia altrui passar per la sua via, ma tanto lo 'mpedisce che l'uccide; (Inf. I. 88-96)

Virgil's reply, which then goes on to prophesy the coming of the Veltro, already seems to discount the possibility of a present fulfillment by advising the pilgrim to take another road. The coming of the Hound appears to be a future event whose realization might never materialize. The other road that the pilgrim is to take, which will lead him through Hell, Purgatory and Paradise, is the road of the poem through the three cantiche; the road that the pilgrim wanted to take but cannot, and which Virgil believes to be a future possibility, is a road the poem never takes. The prophecy of the Veltro is one of two solutions to the pilgrim's predicament and the one which is discarded.

Even so these reasons do not suffice to justify that the reader, in turn, disregard the episode altogether particularly when it is Virgil to utter the prophecy. In conformity to ancient and medieval belief, Virgil has always been regarded as a seer, one who can see in the future and foretell it. In the Veltro episode Virgil has precisely this function but this time his prophetic powers are 
closely linked to his role as a poet. In the first place, the pilgrim appeals to him as a wise man ("famoso saggio") which, as the commentaries explain, means "poet" because the ancient poets were thought to be men of wisdom and poetry was considered a form of learning. This is how Singleton, in his commentary, glosses saggio: "For Dante, as for his time, the ancient poets are savi, men of wisdom and learning, poetry itself being a form of wisdom." ${ }^{6}$ It is as poet and author that the pilgrim knows Virgil and addresses him:

“Or se' tu quel Virgilio e quella fonte che spandi di parlar sì largo fiume?", rispuos'io lui con vergognosa fronte.

"O de li altri poeti onore e lume, vagliami ' 1 lungo studio e 'l grande amore che $\mathrm{m}^{\prime}$ ha fatto cercar lo tuo volume.

Tu se' lo mio maestro e ' 1 mio autore, tu se' solo colui da cu' io tolsi lo bello stilo che $\mathrm{m}^{\prime}$ ha fatto onore. (Inf. I. 79-87)

In addition, Virgil's prophecy seems safely anchored in the Aeneid with the final mention of characters from the epic, "per cui morí la vergine Cammilla, / Eurialo e Turno e Niso di ferute." The reference to the "umile Italia" in line 106 which will benefit from the coming of the Veltro is first of all Virgil's Italy, the Italy of the Aeneid, "Di quella umile Italia fia salute." As some commentators have indicated, the attribute "umile" is a reference to the description of the Italian coastline in the Aeneid when it is first sighted by Aeneas's ships: "humilemque uidemus / Italiam" (Aeneidos III. 522-23). ${ }^{7}$

These references to Virgil the poet and to the Aeneid make possible a plausible explanation of what Virgil might mean by the coming of the Veltro. The lines that describe the coming of Aeneas to the Italian shores mark the beginning of the struggle between the Trojans and the peoples of the Latium that eventually leads to the unification of the two people and to Italy's salute. In the context of the Aeneid, the hero that restores Italy to health is, as we know, Aeneas and it is he who in the poem is characterized as a hound. In the final duel with Turnus, the leader of the Latins, Virgil describes Aeneas running after Turnus as a hound chasing a stag: 
ille autem insidiis et ripa territus alta mille fugit refugitque uias, et uiuidus $\mathrm{Vmber}$ haeret hians, iam iamque tenet similisque tenenti increpuit malis morsuque elusus inani est;

(Aeneidos XII. 749-55, italics mine)

When the hound finally gets the stag, when Aeneas kills Turnus, the hound Aeneas becomes the savior of Italy. Aeneas, in other words, is Virgil's poetic answer to a resolution of conflict. His prophecy of the Veltro is another way of giving his solution to the plight of the pilgrim. As critics have always thought, Virgil is proposing a hero of the stature of Aeneas but what has not been emphasized enough is that this solution is purely a poetic one. At stake is the viability of a literary model such as the one offered by Virgil's Aeneid for a poem like Dante's Commedia.

The fact that Virgil also points to another solution which is the one adopted by Dante, and that we know that the Commedia in no way follows the model of the Aeneid, just as there is no Aeneaslike hero in Dante's poem, makes only too clear the fact that Virgil's proposed model is never adopted by Dante. Rather than deducing from all these factors that perhaps it is not a question of poetic models at all, and that my reading is moving along a false path, we should ask why Virgil's model is rejected, or is not acceptable to Dante, when Virgil is nonetheless made the guide of the pilgrim in two cantiche of Dante's poem.

The unquestioned authority that has always been granted to Virgil by readers of the Commedia is perhaps responsible for the scant attention that Virgil's lines, alluding to the heroes that contributed to Italy's "salute," have received over the years. At first glance, the lines do not seem to present great exegetical problems. Virgil mentions four warriors: Camilla, Euryalus, Turnus and Nisus, who have died for the well-being of their country, Italy. Two fought on Aeneas's side, Euryalus and Nisus, and two against him, Camilla and Turnus.

When we take the bother of looking up these names in the $A e$ neid to find out how they died, we discover, however, to our great surprise, that these heroes did not die fighting for the glory of their country, as Virgil would like us to think. Camilla, for example, is killed while pursuing an enemy but not in battle, but because she is after the gold of his armor:

hunc uirgo, siue ut templis praefigeret arma

Troia, captiuo siue ut se ferret in auro

uenatrix, unum ex omni certamine pugnae 
caeca sequebatur totumque incauta per agmen

femineo praedae et spoliorum ardebat amore,

(Aeneidos XI. 778-82, italics mine)

Blinded by her greed, Camilla exposes herself to danger and becomes the easy prey of a certain Arruns who has been stalking her all along for a chance to strike her, "telum ex insidiis cum tandem tempore capto / concitat . . A Arruns" (Aeneidos XI. 783-84).

Euryalus and Nisus are also killed for similar reasons in similar circumstances. Although they die while on a mission for which they have volunteered - a fact which would justify Virgil's claim that they died for the good of the country -, for at least one of them, Euryalus, this is not the case. The two warriors are on a mission to reach Aeneas to bring back help against the Rutuli who are besieging their camp. They leave at nightfall to cross the enemy lines but as they go through the sleeping enemy camp they slaughter the sleeping enemies and plunder the camp:

impastus ceu plena leo per ouilia turbans

(suadet enim uesana fames) manditque trahitque

molle pecus mutumque metu, fremit ore cruento.

nec minor Euryali caedes. ... (Aeneidos IX. 339-42, italics mine)

Euryalus's bloodlust and greed, which even his friend Nisus finds excessive, "(sensit enim nimia caede atque cupidine ferri)" (354), proves eventually fatal when one of the spoils taken by Euryalus, an helmet, betrays his presence to the approaching enemy cavalry. The helmet, reflecting the light of the moon, attracts the attention of the enemy who slays not only Euryalus but also Nisus who, having already made it to safety, returns to help his friend, "et galea Euryalum sublustri noctis in umbra / prodidit immemorem radiisque aduersa refulsit" (373-75). Once again the reason for the demise of the heroes is greed and excess and not the love of country.

The same can be said of Turnus who, if we read closely, is not killed for having lost the duel to Aeneas in defense of his country. When he is defeated, Turnus pleads for his life and Aeneas is about to let him go unharmed. As he is deciding, Aeneas discovers that Turnus is wearing the baldric of his dead friend Pallas and enraged kills him in just retribution for his act.

Aeneas uoluens oculos dextramque repressit;

et iam iamque magis cunctantem flectere sermo

coeperat, infelix umero cum apparuit alto 
balteus et notis fulserunt cingula bullis

Pallantis pueri, uictum quem uulnere Turnus

strauerat atque umeris inimicum insigne gerebat.

ille, oculis postquam saeui monimenta doloris

exuuiasque hausit, furiis accensus et ira

terribilis: 'tune hinc spoliis indute meorum

eripiare mihi? Pallas te hoc uulnere, Pallas

immolat et poenam scelerato ex sanguine sumit.'

hoc dicens ferrum aduerso sub pectore condit

feruidus. ... (Aeneidos XII. 939-51, italics mine)

Camilla, Euryalus and Nisus are not killed in the service of their country or for its well-being, as Virgil states, but, on the contrary, they die trying to satisfy their greed and violent natures. Their initial honorable and patriotic intentions become, in all three cases, secondary to their self-interest and to their desire to gain wealth which blinds them to everything else and for which they are ready to murder. The larger-than-life hero in revealing his or her all too human nature meets the fate that he deserves.

A close reading of the fate of these heroes in the Aeneid contradicts what Virgil says of them in the Commedia. One explanation could be that Dante ignores how these characters really died and that he is interested in mentioning their names only for the sake of quoting two warriors from each camp. From what has been said, however, it seems highly unlikely that it is a question of random selection. All four characters share too many characteristics for this to be the case. In addition, the phrase "per cui mori" (107) seems to draw attention to the fact that these men sacrificed their lives for their country. Another explanation could be that Dante was not really aware of the real circumstances of their death, or did not care, being interested only in the fact that out of the conflict in which they took part Italy's well-being was achieved. This other hypothesis is improbable on two counts. In the first place, we know how Dante has Virgil remind us that he knows the $A e$ neid by heart, "ben lo sai tu che la sai tutta quanta" (Inf. XX. 114). This reminder is also an invitation to the reader to look further in Virgil's poem for the poet's intentions. And second, and more conclusive for our argument, that while what Virgil says is contradicted by a reading of the Aeneid this is not a misreading of Virgil's poem. These heroes do in fact appear in the Aeneid as Virgil relates in the Commedia.

When we read further in the episode of Camilla we are told that her death will be avenged because she is protected by the goddess Diana. The unheroic circumstances of her death will be kept se- 
cret and, instead, people will know that she died for the glory of her country. This is Opis' promise, Diana's messenger, at Camilla's death:

'heu nimium, uirgo, nimium crudele luisti supplicium Teucros conata lacessere bello! nec tibi desertae in dumis coluisse Dianam profuit aut nostras umero gessisse pharetras. non tamen indecorem tua te regina reliquit extrema iam in morte, neque hoc sine nomine letum per gentis erit aut famam patieris inultae. nam quicumque tuum uiolauit uulnere corpus morte luet merita.' . . . (Aeneidos XI. 841-49, italics mine)

In the Commedia, Camilla appears just as Opis had promised her, as a warrior who died for her country and not as someone who died in dishonorable circumstances.

The same can be said of the two friends, Euryalus and Nisus, who receive at their death a similar promise of glory and immortality:

Fortunati ambo! si quid mea carmina possunt, nulla dies umquam memori uos eximet aeuo, dum domus Aeneae Capitoli immobile saxum accolet imperiumque pater Romanus habebit. (Aeneidos IX. 446-49)

This time the poet intervenes directly to obliterate the real events of their death and to promise eternal glory.

The glorification of Camilla, Euryalus and Nisus are instances of an important motif that is present throughout the Aeneid, the encomiastic theme. As the famous praise of Aeneas's lineage in Book VI illustrates, one of the poem's main objectives is the exaltation of the House of Augustus and of his ancestry. The Aeneid, which accounts for the mythic origins of the Roman Empire, is an indirect vehicle to glorify the past and present greatness of the Romans. In the Camilla episode, Virgil is in reality praising Diana who is a Roman goddess. The facts of her death are concealed because she was devoted to Diana, even though she is an enemy of the Trojans, and thus of Rome. Euryalus and Nisus are Trojans but also best of friends. Their attachment to one another provides the poet with the opportunity not only to praise Aeneas's lineage but also to connect the everlasting power and glory of the Roman Empire with his own immortal poetry ("mea carmina"). Also in this case, the unheroic deeds of these heroes are covered up and falsified by the encomium. 
In making Virgil repeat the praise of these heroes and the lie that they died for the glory of their country, Dante is calling attention to this aspect of Virgil's poetry and to the deceit inherent in encomiastic poetry. It is not difficult to see the substance of Virgil's promise to the pilgrim. Virgil makes the same promise that Opis makes to Camilla or that the poet makes to Euryalus and Nisus. The reasons why this should be so and why the pilgrim needs Virgil's "help," however, are not immediately apparent especially from the way the episode of the pilgrim and the lupa has always been read. It is to this episode, and to the following lines, that I would like to turn now:

Ed una lupa, che di tutte brame sembiava carca ne la sua magrezza, e molte genti fé già viver grame, questa mi porse tanto di gravezza con la paura ch'uscia di sua vista, ch'io perdei la speranza de l'altezza.

(Inf. I. 49-54)

Most commentators have noted that the presence of the lupa signifies the temptation of concupiscence undergone by the pilgrim. ${ }^{8}$ The description of the she-wolf as the personification of greed underlies the ever growing desire that characterizes it and that can never be satisfied, "dopo 'l pasto ha piú fame che pria." (Inf. I. 99) This characteristic is allegorized in the general deceptive nature of the animal which appears to be plentiful when in essence is completely barren. Its substance is only empty desire, "di tutte brame / sembiava carca ne la sua magrezza."

The relation between the pilgrim and the appearance of the she-wolf has been amply documented. John Freccero, for example, in his reading of the "piè fermo," has demonstrated the vulnerability of the pilgrim in his desire to gain the light at the top of the mount. The "firm foot" is the lame foot of the soul denoting a weakness of the will wounded by concupiscence. This weakness hinders the progress of the intellect signified by the right foot. ${ }^{9}$ The appearance of the lupa as cupiditas suggests a similar shortcoming in the pilgrim in his desire to gain the summit. This condition is not clearly discernible at first because of the simple comparison that seems to describe only the effect of the lupa on the pilgrim:

E qual è quei che volontieri acquista, e giugne 'I tempo che perder lo face, che ' $n$ tutti suoi pensier piange e s'attrista; 
tal mi fece la bestia sanza pace,

che, venendomi 'ncontro, a poco a poco

mi ripigneva là dove 'l sol tace. (Inf. I. 55-60)

As Singleton comments, the comparison between "quei" and "la bestia" is only apparent. "This figure amounts to a pseudo-simile, common enough in the poem. . . .10 If we read the simile in terms of the events that it compares we should state in fact that the two terms annull each other. The movement of "quei" who gradually and willingly (volontieri) accumulates (acquista), or gains ground, is undone by the sudden presence of the she-wolf in the second term of the comparison. The she-wolf takes away what had been gained, "a poco a poco / mi ripigneva là dove ' 1 sol tace." The metaphor of gain, as in gaining ground or the summit, suggests, however, another reading where gain is the acquisition of wealth, the accumulation of material goods. Sapegno, in his commentary, has suggested this second possibility whereby the "quei" can be compared to a miser: "come l'avaro, che tende tutta la sua volontà ad acquistare sempre nuovi beni, se viene il momento che gli fa perdere d'un tratto tutto ciò che ha acquistato, si addolora profondamente." 11 If there is a comparison, it would seem to be between the desire of the pilgrim to gain the top of the mount and a miser whose only desire is to accumulate wealth. But the comparison seems to describe more than the desire with which the pilgrim would like to reach the top. As Freccero has indicated, the pilgrim is being confronted with his own greed and it is the awareness of the emptiness of any such desire, symbolized by the lupa, that stops him in his tracks. The pilgrim falls prey of the lupa because he is guilty of the same excess that the animal symbolizes. The lupa functions here as a reminder of the pilgrim's greed and of the vanity of his attempt.

Most commentaries to these lines have understood the pilgrim to be the victim of the she-wolf and have placed the blame entirely on the animal and on the greed it represents. The presence and the promise of Virgil are then easily explained by a future event when the lupa will finally be vanquished. What I am suggesting, instead, is that the blame lies entirely on the pilgrim and that the lupa is only Dante's way of reminding us of the fact. The pilgrim hopes to get quickly to the top in much the same way that Virgil's heroes crave the possessions of others and both act of their own free will. The analogy between the pilgrim and the characters of the Aeneid is not casual in fact. The same desire to gain, in both cases, makes the individual forgetful of his true duties and brings about his undoing. 
This similarity explains the pilgrim's call for help and Virgil's reply and solution. As a good reader of the Aeneid, the pilgrim knows that Virgil has helped others in similar circumstances. He knows that Virgil will overlook the events, place the blame on others, and conceal his shortcomings with praise. We know that this is what Virgil promises him when he alludes to his characters who now appear as heroes and not as the men they really are. There is one other detail, however, that must be mentioned now which explains better the pilgrim's request and Virgil's reply. In the one case of poetic "justice" in the Aeneid, the death of Camilla is blamed entirely on the man who kills her, a certain Arruns. We are never told why Arruns followed Camilla everywhere for a chance to kill her but his tireless pursuit has all the trademark of fate. When he does kill her, Virgil's description of the event makes him look like a coward who has struck a poor defenseless woman. Virgil compares him to a wolf who has killed a shepherd or a big steer and knows he has done wrong:

ac uelut ille, prius quam tela inimica sequantur,

continuo in montis sese auius abdidit altos

occiso pastore lupus magnoue iuuenco,

conscius audacis facti, caudamque remulcens

subiecit pauitantem utero siluasque petiuit:

haud secus ex oculis se turbidus abstulit Arruns

contentusque fuga mediis se immiscuit armis.

(Aeneidos XI. 809-15, italics mine)

Opis's slaying of Arruns in vengeance for the death of Camilla signifies also the symbolical death of the wolf. With this in mind, the pilgrim's request is more than justified and Virgil's reply not in vain. As a reader of the Aeneid, the pilgrim knows from a parallel example that he can expect a similar form of justice. This justice is markedly one-sided and in favour of the authorities it serves. It not only conceals the crimes of those whose patrons it seeks to please but also distorts the truth of events whereby the guilty are said to be victims and their just fate an injustice. If we had not read the rest of the poem and took Virgil at his word, we could expect to be reading a poem about a man very much like Aeneas who restores order to a strife-torn Italy. The poem would sing the praise of the powers it served and would be characterized by a similar system of bipartisan justice in favour of those whose protection it sought.

We know already that this is not the case with Dante's poem but the reason is that Virgil's poetic model, which he proposes 
through the prophecy of a coming Veltro, is rejected on account of its biased system of justice. The critique of this model is made clear not only in the two opposed solutions that Virgil gives, only one of which is correct, but also in the way in which Dante constructs the episode. When we observe closely the list of warriors mentioned by Virgil we realize that Turnus does not really fit in with the rest of them. Although he is an example of greed like the rest, it cannot be said that Turnus died for the well-being of Italy. Viewing it from the point of view of the Trojans, Turnus is an obstacle and a detriment to that well-being. Only his death brings about the peace and unity that Virgil is extolling. Virgil, in fact, does not avenge him or celebrate him like he does the others, even though the others are just as guilty as he is. Turnus, instead, is more on the side of characters like Arruns. They are personifications of evil whose ritual death at the hands of the gods is an affirmation of justice and an end to all injustices.

Turnus's presence among the other warriors is conspicuous for another reason. In the series of names, Turnus is placed between Euryalus and Nisus, two characters who are really part of one episode, "Eurialo e Turno e Niso di ferute." It would have been more appropriate if Turnus had been mentioned last as yet another example. The presence of Turnus amongst them is, however, more dramatic and relevant when we remember that Euryalus and Nisus are said to be the best of friends in the Aeneid. The two never separated, they were always together, when they went to battle they went together, when one volunteered for the mission the other also went. Virgil says of them: "his amor unus erat pariterque in bella ruebant" (Aeneidos IX. 182, italics mine). We have mentioned how Nisus, who in the meantime had reached safety, returns to help his friend who has been caught by the enemy. They fight together and when they are killed their bodies are found together. "tum super exanimum sese proiecit amicum confossus, placidaque ibi demum morte quieuit" (Aeneidos IX. 444-45, italics mine). When Virgil sings their praise, as I have already quoted, he celebrates their inseparability which he adopts as the symbol of the unity between his poetry and the House of Augustus. As long as Virgil's poetry will be influential and the Romans will be in power the memory of the two inseparable friends shall never be forgotten. The symbolic importance that the two friends have for Virgil in the Aeneid makes highly significant, therefore, the placing of Turnus, the symbol of discord in the Aeneid, between the two friends. ${ }^{12}$ 
The disruptive presence of Turnus has many implications. The separation of the two friends means first of all that their memory as a "fortunati ambo" has been indeed obliterated and replaced by the memory of their greed which is the cause of their death. The union of poetry and political power that the two symbolize is also broken and not only because the House of Augustus no longer rules the world. The break, which implies a critique of the encomiastic poetry we have in the Aeneid, points to the history of greed and deceit which is concealed under the lie of a history of noble and selfless acts performed for the glory of one's country. As a result, even the fiction of a "pious Aeneas" becomes suspect not only because he is the embodiment of the noble and selfless man, and the ancestor of Augustus, but also because he is the instrument of a justice which is corrupt.

The reappearance of Turnus amongst Virgil's heroes points to the shortcomings of Virgil's politically compromised system of justice. A poetic justice that conceals the aberrations on which political power is constructed and slavishly flatters the powerful. Consequently, Virgil's own motives are in question here and his greed for which he compromised his poetic integrity. Virgil partly expiates for his sin when he is made to confess that he lived "a Roma sotto 'l buono Augusto / nel tempo de li dèi falsi e bugiardi" (Inf. I. 71-72). He will expiate his cupiditas in Purgatorio XII. ${ }^{13}$

The reappearance of Turnus means also that the resolution of the conflict at the end of the poem, with the death of Turnus, is only a poetic fiction and that "evil" has not been exorcised. Virgil's promise of a Veltro who will restore Italy to health is only a nice fiction which is no longer acceptable. The fiction of a new Aeneas would only perpetuate the evil under a compromised system of justice where definitions of good and evil are decided on the bases of political power and not of merit. For these reasons, at the level of a poetics of the Commedia, Virgil's proposal and poetic model is rejected and the Commedia takes another road, a road of a different type of justice, as we shall see.

At this point, and before we go on to describe Dante's version of the Veltro, it must be said that if Dante rejects Virgil's poetic model this does not mean that he rejects the Aeneid or Virgil. Dante rejects only the idea of a poem like the Aeneid that courts the favour of the powerful it glorifies. I also do not mean to say that Virgil was taken in by his own fiction. There is sufficient evidence to believe that the myth of Aeneas and of the glorious Roman people is also put into question by Virgil. The glorifica- 
tions of Camilla and of Euryalus and Nisus are treated ironically as Virgil first elaborates in detail on their base and unheroic actions and then praises them. This is more clear in the case of Turnus's death at the end of the Aeneid which, abruptly, marks the end of the poem. As I have said, Aeneas first grants Turnus his life and then kills him because he has murdered Pallas. There is reason to believe, reading between the last lines of the poem, that Aeneas's justification for killing Turnus is suspect and that the poet wanted to call attention to Aeneas's act of injustice when he describes Turnus's indignance ("indignata") at Aeneas's "excuse" for killing him: "ast illi soluuntur frigore membra / uitaque cum gemitu fugit indignata sub umbras" (Aeneidos XII. 951-52, italics mine). Dante rejects in Virgil only the compromise that places poetry at the service of political power for personal gain. Like Camilla's desire for gold, Euryalus's helmet, Turnus's baldric, or the pilgrim's lupa, the presence of Turnus's amongst Virgil's heroes points to the poet's greed for which he willingly compromised his art in exchange for a comfortable living, as Juvenal ironically points out in the seventh satire. "Nam si Vergilio puer et tolerabile deesset / hospitium, caderent omnes a crinibus hydri" (Satura VII. 69-70). ${ }^{14}$

The ironic presence of Turnus is Dante's way of undermining Virgil's tempting but illusive poetic model. Dante rejects the fiction of a Veltro, of a pious and noble man, who is above the greed and the deceptions of ordinary men, capable of bringing about the resolution of political and social conflicts. The tendency to take Virgil's prophecy literally and to accept him as the voice of authority in the Commedia, has made the reader overlook an important detail in the description of the Veltro that might have alerted him to Dante's critique of Virgil's model and to Dante's very different Veltro. The lines in question are the following:

Questi non ciberà terra né peltro, ma sapïenza, amore e virtute, e sua nazion sarà tra feltro e feltro. (Inf. I. 103-05)

These lines have always been read as the description of the new personage to come who "will not feed on earth or pelf, but on wisdom, love and virtue, and his birth shall be between felt and felt." This is Singleton's translation but it is also the way these lines are always rendered in English. This is the reading that Virgil would like us to believe and which distracts us from another reading and from the fact that the verb cibare in "Questi non 
ciberà" is not used reflexively as it should be if it were meant to refer to a person. If it had been a question of a person the lines should have read, even in the Italian of Dante, "Questi non si ciberà di." Dante uses cibare in the transitive active voice meaning feeding others rather than oneself. That is to say that speaking of the Veltro, Dante is saying that it will not feed neither land nor wealth, but wisdom, love and virtue, and its nation will be between two felts.

The verb cibare is used in the same transitive active voice two other times in the Commedia. In one instance the verb is used to describe the feeding of the blessed by the Agnus Dei at the Celestial Banquet:

"O sodalizio eletto a la gran cena del benedetto Agnello, il qual vi ciba sí, che la vostra voglia è sempre piena, (Par. XXIV. 1-3)

The other time, the occasion is a human banquet and this time it is a book, Dante's Commedia, that feeds the reader:

Or ti riman, lettor, sovra 'l tuo banco, dietro pensando a ciò che si preliba, s'esser vuoi lieto assai prima che stanco.

Messo t'ho innanzi: omai per te ti ciba; ché a sé torce tutta la mia cura Quella materia ond'io son fatto scriba. (Par. X. 22-27)

In both examples the verb cibare is used to describe the activity of giving spiritual sustenance and knowledge. In the latter case, the verb refers specifically to the teachings one finds in Dante's poem which the poet, as the scribe of his poem, offers to the reader for his edification.

A similar idea is behind the use of cibare in the episode of the Veltro. Since we are in the prologue canto of the Commedia, the prophecy of the Veltro is a way of saying that the poem to come will not teach the reader how to become successful in business and wealthy; rather it will teach him wisdom, love and virtue. To the riddle of the Veltro and to the question "What is the thing that feeds neither land nor pelt but only wisdom, love and virtue and its domain is between two felts?" the answer is Dante's Commedia, the book the reader is about to read. The last line, "e sua nazion sarà tra feltro e feltro," reading with most commentators "nazion" as "domain," describes the space of a book whose domain is between two covers lined with felt. The felt lining is in accordance 
with the humble and unassuming character of the book and its modest aims. At the time of Dante, books could be covered with intricate and costly covers and, very often, they were lined with velvet. ${ }^{15}$ The emphasis on felt, the cheapest material, places the stress on the spiritual and moral goals of the poem and deemphasizes the materialistic and the opportunistic values which the poem is combatting.

The practice of using the imagery of feeding, in the sense of teaching, and in a prologue to acquaint the reader with the content of the work to be read, is not new with Dante who used a similar technique in the Convivio. ${ }^{16}$ This important theoretical work, whose main concern is to teach the reader how to read allegorical poems, employs the imagery of food and feeding to explain to the reader what he can expect from a work which is appropriately entitled The Banquet.

La vivanda di questo convivio sarà di quattordici maniere ordinata, cioè quattordici canzoni sí d'amor come di vertú materiate, le quali sanza lo presente pane aveano d'alcuna oscuritade ombra, sí che a molti loro bellezza piú che loro bontade era in grado. Ma questo pane, cioè la presente disposizione, sarà la luce la quale ogni colore di loro sentenza farà parvente. (Convivio I. 14-16)

The reader is invited to a banquet where he will be taught how to read the canzoni according to their allegorical meaning and not simply to enjoy them. The Convivio, Dante tells us, needed to be written because the reader seduced by the beauty of the poems simply enjoyed them but did not read them allegorically for the moral lessons ("bontade") they meant to convey. "E con ciò sia cosa che la vera intenzione mia fosse altra che quella che di fuori mostrano le canzoni predette, per allegorica esposizione quelle intendo mostrare, appresso la litterale istoria ragionata . . ." (Convivio I. 18-19).

The prologue canto of the Commedia shares with the introduction of the Convivio not only the imagery but also a similar preoccupation. This is expressed as the liberating action of the Veltro and is the way in which the Commedia will teach wisdom, love and virtue:

Questi la caccerà per ogne villa,

fin che l'avrà rimessa ne lo 'nferno,

là onde 'nvidia prima dipartilla. (Inf. I. 109-11) 
When these lines are read in terms of our reading of the Veltro, we become aware that, differently from what happens in the episodes of Camilla and Turnus, Dante's Veltro does not pretend to kill the lupa, that is to resolve the problem of evil and vanquish it, but only to put it back in Hell whence it came. In Dante's poem there can be no illusion that evil can be exorcised once and for all through the punitive action of a god or a pious man. The reappearance of Turnus in Dante's poem makes this clear. The killing of the lupa is Virgil's fiction not Dante's.

The lupa does not symbolize envy, as the wolf represents evil in the Aeneid, so that its defeat at the hands of the Veltro can signify the successful overcoming of evil. The lupa in the Commedia, as I have indicated, is only a sign pointing to the presence of greed and of envy. As a sign, the lupa points to those who are guilty of this $\sin$ in very much the same way as the helmet points to Euryalus's greed, Pallas's baldric betrays Turnus's, and the presence of Turnus amongst Virgil's warriors Virgil's own avidity. These are signs that point to a deceit or a transgression which makes it possible to uncover it and to punish it. The task of Dante's Veltro will be to hunt down these examples of greed found in every city of the "umile Italia" and to place them where they belong in Hell or in Purgatory. He will look for Florentines, Romans, Greeks and everyone whose baseness is concealed by an apparent noble character. In the terms of Dante's allegorical representation, to place the lupa in Hell means to bring about in the reader the moment of recognition of a particular evil or crime which is how the Commedia will teach its readers to become wise, loving and virtuous.

Dante's objective in the Commedia is to teach the reader to go beyond the mere letter of poetic representation to unveil the truth that it conceals, in very much the same way in which he is to learn to go beyond the appearances of things to the truth behind. In the Convivio, the mode of representation which the poet uses to convey his moral teachings is called the allegory of poets and consists of two concurrent but different levels of meaning: the literal and the allegorical:

L'uno si chiama litterale, (e questo è quello che non si stende piú oltre che la lettera de le parole fittizie, sí come sono le favole de li poeti. L'altro si chiama allegorico,) e questo è quello che si nasconde sotto ' 1 manto di queste favole, ed è una veritade ascosa sotto bella menzogna: sí come quando dice Ovidio che Orfeo facea con la cetera mansuete le fiere, e li arbori e le pietre a sé muovere; che vuol dire che lo savio uomo con lo 
strumento de la sua voce fa(r)ia muovere a la sua volontade coloro che non hanno vita di scienze e d'arte: e coloro che non hanno vita ragionevole alcuna sono quasi come pietre. (Convivio II. i. 3-4)

The first meaning, the literal, is always only a sign that posits the possibility of meaning, that is, of another meaning to which it alludes, the meaning of the allegory. In the now famous letter to Cangrande, Dante gave the etymology of allegory as that which is other, different. "Nam allegoria dicitur ab 'alleon' grece, quod in latinum dicitur 'alienum', sive 'diversum'."17 In mimetic or symbolic representation, the signification is direct and unmediated. A set number of conventions govern the relation between sign and referent. The symbols employed are to a large extent part of an established system of meanings and one needs only to establish the connection to decode the meaning of the symbol. In allegory the meaning is other than what appears to be at first. The literal meaning is only a fiction, a "bella menzogna," whose purpose is to hide the allegorical truth to which it points. Differently from the symbol, poetic allegory is not so easily determined because it does not depend on a reliable system of meanings for its expression. In poetic allegory, it is the meaning the poet gives to the fiction that is at stake.

In the letter to Cangrande, Dante explains what these two levels are. The poetic fiction is the journey in the three realms or, more specifically, the representation of the state of the souls after death. "Est ergo subiectum totius operis, litteraliter tantum accepti, status animarum post mortem simpliciter sumptus; nam de illo et circa illum totius operis versatur processus" (Epistola XIII. 24-25). The allegorical meaning, however, is in function of the system of justice that punishes or rewards men's actions voluntarily undertaken. "Si vero accipiatur opus allegorice, subiectum est homo prout merendo et demerendo per arbitrii libertatem iustitie premiandi et puniendi obnoxius est" (Epistola XIII. 25-26). The meaning of the allegory is the judgment of man as he is deserving or undeserving because of actions dependent on his free will. Unlike the type of justice that exists in the Aeneid, this justice is impartial because it is not compromised by political affiliations and personal gain. For these reasons, Dante's justice becomes an extension of divine justice, true justice, whereas the one found in the Aeneid, as it is clear from the Camilla episode, is an example of the "justice" "de li dèi falsi e bugiardi." The substance of Dante's fictitious journey through Hell, Purgatory and Paradise is to show the reader different examples of vices and virtues for his edification. 
The process through which these teachings are imparted, however, is not always clear and transparent as the episode of Virgil's prophecy of the Veltro has shown. Virgil's vice must be deduced by going beyond the meaning of the letter to the hidden meanings, and truth, that it conceals. This is where the Convivio and the Commedia differ. In the earlier work, Dante sets out to explain to the reader the meaning of his poems that he has missed, in the Commedia the reader is on his own. He has to read the poem allegorically and uncover the deceit himself if he wants to become wise, loving, and virtuous. Through this process of reading, or of "feeding" to use Dante's metaphor as it is employed in Paradiso X, the reader gradually learns and, supposedly, also journeys from Hell to Paradise. The reference to feeding in Paradiso $X$ underscores this necessity, namely, that the reader can reap the rewards only if he is capable of eating the food that the poem feeds him, "Messo t'ho innanzi: omai per te ti ciba. . .."

The episode of Virgil provides an example of how Dante's allegorical mode of representation works and of how his justice is carried out. Virgil's lie of noble and selfless heroes is exposed through the presence of Turnus which disrupts the authority of Virgil's poetic word. Once the presence of the discordant element is perceived, namely the sign that points to the infraction, the awareness brings about the moment of judgment. In the case of Virgil, the ironic presence of Turnus is sufficient to expose Virgil's bias and to undermine the validity of his claims.

Through this ironic mode of signification, the souls in Inferno and in Purgatorio are made to reveal their wrongdoings which is not immediately apparent at a first reading. Encountering Paolo and Francesca, Brunetto Latini or Ulisse, to name only a few of the most well-known "heroes" of the Inferno, the reader has often been at a loss to justify their presence in Hell. In the case of Virgil there has never even been the suspicion of a possible deception. But as for Virgil, what is related by the souls is always a lie that can never be taken at its face value but must be unmasked before the truth can be known. This task is given to the reader who is called upon to perform a similar critical task that Dante put into practice in the Convivio. This is the task to go beyond the seduction of the language of love of Francesca, the promise of immortality of Brunetto Latini and the rhetoric of Ulisse, to make manifest the truth that their language conceals. ${ }^{18}$ Through irony, Dante's instrument of justice, the poet brings about the sudden recognition that reveals the soul's deception and justifies its place in Hell or Purgatory. 
Allegory and irony are the two representational modes employed by Dante's Veltro, his Commedia, to bring justice to the deserving and the undeserving, and thereby to teach wisdom, love and virtue to those who are willing to take up the task of reading the poem. Cacciaguida, commenting on the doctrinal function of the poem in Paradiso XVII and once again using a food metaphor, alludes to the inherent difficulties in this task of allegorical interpretation:

indi rispuose:" Coscienza fusca

o de la propria o de l'altrui vergogna

pur sentirà la tua parola brusca.

Ma nondimen, rimossa ogne menzogna,

tutta tua vision fa manifesta;

e lascia pur grattar dov'è la rogna.

Ché se la voce tua sarà molesta

nel primo gusto, vital nodrimento

lascerà poi, quando sarà digesta. (Par. XVII. 124-32)

The implication in these lines is that the reader is also necessarily involved in the subject matter of the poem. ${ }^{19}$ The act of reading necessary to unveil the deception of the beautiful lie requires a similar unveiling in the reader engaged in the act of interpretation. The reader's relationship to the poem is not unlike that of the pilgrim to Virgil. It requires, as its necessary precondition, the refusal of the lie of an easy and factitious solution and an avowal of the basically corrupt nature of man from which the reader is not exempt. Only on this condition, it would appear, the reader can benefit from the poem or, to put it in terms of the Convivio, only when the food of the poem is consumed with the bread of commentary can the "real" beauty of Dante's poem be appreciated.

The first canto of the Commedia is an allegory of this process in the initial demistification of the pilgrim's attempt to reach the "dilettoso monte" (Inf. I. 77) quickly and directly. The precondition for the journey, or the reading, is in the realization of a selfdeception whose foundation seems to be rooted in a mistaken conception of self and its powers which, at the level of poetic representation, has its equivalent in the deluded belief in the validity of a symbolic conception of art. Virgil's dual reply, to take another road and to look forward to a new Veltro, allegorizes the deception inherent in a symbolic mode of reading the poem which, as the embodiment of a desire, turns fiction into reality; and, second, it points to the indirect path of allegorical representation. To 
be sure, there is only one road and its precondition is the awareness of the deceptive nature of the other road which, although easier, more direct and more pleasurable, leads the traveller nowhere when it does not lead him to his downfall.

The allegory of irony that defines the Commedia is exemplified by the relationship between the pilgrim and Virgil in the Inferno and Purgatorio, and between the pilgrim and Beatrice in the Paradiso. ${ }^{20}$ These two are the beautiful lies which must always come before in an allegorical poem in order to point the way but from which the truth is always and inevitably severed. At the end of the prologue canto, after the subject matter of the poem has been announced allegorically, the journey, which is the poem, begins with Virgil's beautiful lie leading the way and Dante's truth following right behind: "Allor si mosse, e io li tenni dietro" (Inf. I. 136).

University of Alberta

\section{NOTES}

1 All references to Dante Alighieri's La Commedia are to the edition of the Società Dantesca Italiana, La Commedia secondo l'antica vulgata, ed. Giorgio Petrocchi (Milano: Arnoldo Mondadori Editore, 1966).

2 Jean Pépin, Dante et la tradition de l'allégorie (Montréal: Institut d'études médiévales, 1970), p. 152.

3 R.E. Kaske, "Dante's DXV and Veltro," Traditio, 17 (1961), 185-254. Contains a good recapitulation of previous interpretations of the Veltro.

4 See John D. Sinclair's commentary to Inferno I in The Divine Comedy: Inferno, trans. John D. Sinclair (New York: Oxford University Press, 1967), p. 32.

5 Sinclair, p. 32.

6 Commentary to Inf. I. 89 in The Divine Comedy: Inferno, comm. Charles S. Singleton, Bollingen Series LXXX (New Jersey: Princeton Univ. Press, 1970).

7 P. Vergilius Maro, Aeneidos in Opera, ed. R.A.B. Mynors (Oxford: At the Clarendon Press, 1969). Henceforth all references are given in the text.

8 See for instance Singleton's commentary to Inf. I. 94-101.

9 John Freccero, "Dante's Firm Foot and the Journey Without a Guide," Harvard Theological Review, 52 (1959), 245 ff.

10 Singleton's commentary to Inf. I. 55-60.

11 See Natalino Sapegno's commentary to Inf. I. 55 in La Divina Commedia, comm. Natalino Sapegno (Milano and Napoli: Ricciardi, 1967).

12 Petrocchi in his commentary to Inf. I. 108 defends the order Eurialo, Turno, Niso but for different reasons. "Le varianti che elencano nell'ordine i nomi Eurialo - Niso - Turno, nascono dall'arbitrio di copisti che hanno affiancato i due amici Eurialo e Niso, mentre Dante ha inteso esplicitamente alternare un eroe d'un campo con altro dell'esercito avverso: Camilla ed Eurialo, Turno e Niso."

13 The discussion of Virgil's cupiditas is taken up in Purgatorio XXII in Virgil's meeting with Statius.

14 Iunius luvenalis, Saturae, ed. E.G. Hardy (Great Britain: MacMillan St Martin's Press, 1970). 
15 In medieval times books were scarce but those few in existence like Missals or copies of the Gospel were often bound in gold and precious jewels. These sacred books so bound were only the property of emperors. See John Hannett, An Inquiry into the nature and form of the books of the ancients; with a history of the art of bookbinding, from the times of the Greeks and Romans to the present day interspersed with bibliographical references to men and books of all ages and countries, illustrated with numerous engravings by John Andrews Arnett (London: R. Groomridge, 1837), p. 54 ff. Less expensive binding, prior to the introduction of printing, was done by adapting wooden boards for side covers. Skin or parchment would be sewn on these boards. "When the boards were first covered," notes Hannet, "it appears that a common parchment or vellum, made from the skin of the deer, was used" (p. 62). Later on, velvet became the most often used material, "used for the covers of the best works" (pp. 62-63) such as the Bible. Dante's remark that the covers of his Commedia are lined with felt stresses the simplicity of its appearance in contrast to the usual practice of bookbinding where the emphasis is on ornamentation. The choice of felt is consonant with the underlying idea that the poem shall lead man to virtue and not to riches. The general thrust of the poem, as I have said, is to go beyond the deceptive richness of appearances to the truth within. The reading of "feltro" as felt lining has been suggested many times by critics who have recalled the use of felt that lined the wooden interiors of medieval ballot boxes. See L. Olschki, The Myth of Felt (Los Angeles: Univ. of California Press, 1949).

16 All references to the Convivio are to the critical edition of Maria Simonelli (Bologna: Riccardo Patron, 1966).

17 Epistola XIII. 22-23 in Dante Alighieri, Tutte le Opere, ed. Fredi Chiappelli (Milano: Mursia, 1965).

18 This is not to say that past or present commentators have ignored this task. To be sure there are many examples, too many to quote here, where the critic has performed a similar demystification of the text to arrive at the truth behind the representation. To quote only two of the most noteworthy examples of readings of the Ulysses's episode: John Freccero, "Dante's Prologue Scene: II. The Wings of Ulysses," Dante Studies, 84 (1966), 12-25; Giuseppe Mazzotta, "Poetics of History: Inferno XXVI," Diacritics, 5 (1975), 37-44 now reprinted in a slightly altered form as Chapter 2 of Dante, Poet of the Desert (History and Allegory in the Divine Comedy) (Princeton: Princeton Univ. Press, 1979).

19 One of the key passages where the reader is implicated directly, as John Freccero has shown is the Medusa episode in Inf. IX. See John Freccero, "Medusa: the Letter and the Spirit," Yearbook of Italian Studies, 2 (1972), 1-18.

20 As Dante reminds us in the letter to Cangrande, the general subject matter of the Paradiso is slightly different. At issue is not whether the souls are or are not deserving, rather that being all deserving they are justly rewarded. At the literal level, is described "status animarum beatarum post mortem," and at the allegorical level, "est homo prout merendo obnoxius est iustitie premiandi" (Epistola XIII. 33-35). 